\title{
EVALUATION OF THE FINNISH DIABETES RISK SCORE (FINDRISC) FOR DIABETES SCREENING IN OCCUPATIONAL HEALTH CARE
}

\author{
GODELIEVE JOHANNA MAURICE VANDERSMISSEN ${ }^{1}$ and LODE GODDERIS ${ }^{1,2}$ \\ ${ }^{1}$ Groep IDEWE, External Service for Prevention and Protection at Work, Heverlee, Belgium \\ ${ }^{2}$ Katholieke Universiteit Leuven, Leuven, Belgium \\ Occupational, Environmental and Insurance Medicine
}

\begin{abstract}
Objectives: The objective of the study was to investigate the prevalence of undiagnosed dysglycaemia and the risk for type 2 diabetes using the Finnish Diabetes Risk Score (FINDRISC) in the working population of Belgium. Moreover, it was to evaluate performance and applicability of FINDRISC as a screening tool during occupational health surveillance. Material and Methods: A cross-sectional analysis was carried out over the years 2010-2011 among 275 healthy employees who underwent a health check including fasting plasma glucose and the FINDRISC questionnaire. The sensitivity, specificity and predictive value of different FINDRISC cut-off values to detect dysglycaemia was revised in the literature and then calculated. Results: The prevalence of unknown dysglycaemia was 1.8\%. Twelve percent of the employees had a FINDRISC score of 12 to 14 corresponding to a moderate risk of $17 \%$ to develop diabetes within the next 10 years, and $5.5 \%$ had a score of 15 or more corresponding to a high - very high risk of $33 \%$ to $50 \%$. All dysglycaemic individuals had a FINDRISC score of 12 or higher. The sensitivity and specificity for detecting dysglycaemia was respectively $100 \%$ and $84.1 \%$ for a FINDRISC cut-off value $\geq 12$; and $80 \%$ and $95.9 \%$ for a cut-off value $\geq 15$. Conclusions: A considerable number of workers had dysglycaemia or was at risk for developing type 2 diabetes. The questionnaire is a reliable, valuable and easy to use screening tool in occupational health surveillance.
\end{abstract}

Key words:

Diabetes Mellitus, Occupational Health, Questionnaires, Cross-Sectional studies

\section{INTRODUCTION}

Type 2 diabetes is a common chronic disease in the general as well as in the working population [1-3]. Approximately $7-30 \%$ of diabetes cases remain undiagnosed [1,2]. In addition, there is a significant number of individuals with impaired fasting glucose (IFG) or impaired glucose tolerance (IGT), who are at risk of developing diabetes if no actions are undertaken [1,2]. An important risk factor for diabetes, besides a person's genetic background, is overweight due to an unhealthy lifestyle. Diabetes results in the increased sickness absence, morbidity and mortality [4].
The use of validated risk calculators to quickly identify and subsequently follow-up people at a high risk of type 2 diabetes is recommended by several international organizations [5,6].

The Finnish Diabetes Risk Score (FINDRISC) questionnaire is a validated risk assessment tool to predict type 2 diabetes [7]. It estimates the probability of a person to develop diabetes within the next 10 years.

Diabetes risk calculation can be performed by several health professionals in different settings such as Occupational Health Care (OHC). Occupational health care traditionally

Received: August 1, 2014. Accepted: November 12, 2014.

Corresponding author: G. Vandersmissen, Groep IDEWE, Interleuvenlaan 58, 3001 Heverlee, Belgium (e-mail: lieve.vandersmissen@idewe.be). 
focuses on prevention of work-related illnesses and injuries. Recently international institutes, like the Occupational Safety and Health Administration (OSHA), have widened the scope towards Workplace Health Promotion (WHP) [8]. The aims of the current study were to investigate the prevalence of undiagnosed dysglycaemia and the risk for type 2 diabetes using the FINDRISC questionnaire in a working population. Moreover, performance of FINDRISC as a screening tool for undetected dysglycaemia and its applicability in $\mathrm{OHC}$ were evaluated.

\section{MATERIAL AND METHODS}

All data were collected during the period 2010-2011 from the workers undergoing a voluntary health check by one single occupational physician of a Belgian External Service for Prevention and Protection at Work. This health check comprises a medical examination, electrocardiography (ECG), lung function test, urine analysis and a standard fasting blood analysis including glycaemia. For this study, additionally, 8 questions of the FINDRISC questionnaire were addressed. The use of the data collected during health surveillance for research purpose was approved by the ethics committee.

Because 2-h plasma glucose results were not available, dysglycaemia was defined as the presence of diabetes or impaired fasting glycaemia (IFG). Impaired fasting glycaemia was considered a fasting glycaemia between $110 \mathrm{mg} / \mathrm{dl}$ and $125 \mathrm{mg} / \mathrm{dl}$, diabetes as $126 \mathrm{mg} / \mathrm{dl}$ or more [9].

The maximum value of the FINDRISC score is 26 . FINDRISC lower than 7 is considered to denote a very low diabetes risk, 7-11 a low risk, 12-14 a moderate risk, 15-20 a high risk and 21 or more a very high risk, corresponding to a probability to develop diabetes within the next 10 years of $1 \%, 4 \%, 17 \%, 33 \%$ and $50 \%$, respectively [7,10].

The predictive value of different FINDRISC cut-off values to detect dysglycaemia was evaluated by revising the literature and calculating sensitivity (the probability that the test is positive for the subjects who have dysglycaemia) and specificity (the probability that the test is negative for the subjects without dysglycaemia). Statistical Package for the Social Sciences (SPSS) version 19 for Mc Intosh was used for all the statistical analyses. It was also used for descriptive statistics and calculation of sensitivity and specificity of the Finnish Diabetes Risk Score.

\section{RESULTS}

Complete data on 275 employees with unknown diabetes were available. Of these employees, $57.1 \%$ were male (age: mean $(M)=44.7 \pm 9.4$ years). The prevalence of unknown dysglycaemia was $1.8 \%$. Mean FINDRISC was $6.8 \pm 4.7$. Distribution of the results of the FINDRISC questionnaire is shown in Figure 1. Twelve percent of the employees had a moderate risk for type 2 diabetes of $17 \%$, and another $5.5 \%$ had a high or very high risk of $33-50 \%$ to become diabetic in the next 10 years. Of the 5 dysglycaemic individuals in this study all had a FINDRISC score of $\geq 12$ and 4 out of 5 had a FINDRISC score 15 or over. The sensitivity and specificity for detecting dysglycaemia was $100 \%$ and $84.1 \%$ respectively for a cut-off value $\geq 12$ and $80 \%$ and $95.9 \%$ for a cut-off value $\geq 15$.

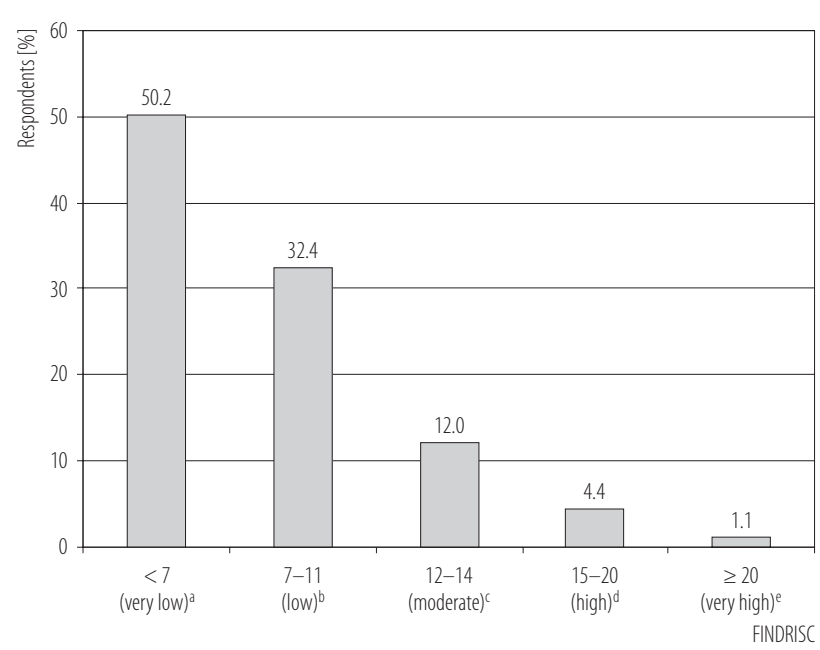

Corresponding estimated diabetes probability within 10 years: a $1 \%,{ }^{\mathrm{b}} 4 \%,{ }^{\mathrm{c}} 17 \%,{ }^{\mathrm{d}} 33 \%,{ }^{\mathrm{e}} 50 \%$.

Fig. 1. Distribution of Finnish Diabetes Risk Score (FINDRISC) in the study population $(\mathrm{N}=275)$ 


\section{DISCUSSION AND CONCLUSIONS}

The prevalence of dysglycaemia in this study $(1.8 \%)$ was lower than the prevalence described by Viitasalo et al. among the Finnair personnel (12.9\%) [3]. This could be due to the fact that in the Finnair study the definition of dysglycaemia, besides IFG and diabetes, also comprised impaired glucose tolerance (IGT). Therefore, we assume the prevalence of dysglycaemia would have been higher if 2-h fasting glucose had been available. Mean FINDRISC ( $6.7 \pm 4.9$ in men, $7 \pm 4.6$ in women) and the prevalence of FINDRISC $\geq 15$ (5.5\%) were comparable to the results of the Finnair study $(6.9 \pm 4.5$ in men, $6.2 \pm 4.6$ in women, and 5.9\%, respectively) [3]. Gyberg et al. have found a prevalence of FINDRISC $\geq 15$ in an online workplace survey in a university hospital in Sweden of 8.4\% [11]. We found a sensitivity of $100 \%$ and a specificity of $84.1 \%$ for detecting dysglycaemia using a cut-off value $\geq 12$, which means that it would have been sufficient to take blood samples from the 48 subjects (17.5\%) with FINDRISC $\geq 12$ to identify the 5 dysglycaemic persons in this study.

Performance of FINDRISC as a screening tool for undetected diabetes or prediabetes has been evaluated in larger studies. As demonstrated in the literature overview (Table 1), sensitivity and specificity data differ among

Table 1. Literature overview of sensitivity and specificity of the different Finnish Diabetes Risk Score (FINDRISC) cut-off values for the detection of dysglycaemia in the subjects with unknown diabetes

\begin{tabular}{|c|c|c|c|c|c|c|c|}
\hline \multirow[b]{2}{*}{ Reference } & \multicolumn{3}{|c|}{ Study population } & \multirow[b]{2}{*}{$\begin{array}{l}\text { FINDRISC } \\
\text { cut-off value }\end{array}$} & \multirow[b]{2}{*}{$\begin{array}{c}\text { Diagnosis } \\
\text { of dysglycaemia }\end{array}$} & \multirow[b]{2}{*}{$\begin{array}{c}\text { Sensitivity } \\
{[\%]^{\#}}\end{array}$} & \multirow[b]{2}{*}{$\begin{array}{c}\text { Specificity } \\
{[\%]^{\#}}\end{array}$} \\
\hline & description & $\begin{array}{l}\text { respondents } \\
{[\mathrm{n}]}\end{array}$ & $\begin{array}{c}\text { age } \\
\text { [years] } \\
(\mathrm{M})\end{array}$ & & & & \\
\hline $\begin{array}{l}\text { Tankova } \\
\text { et al. [12] }\end{array}$ & $\begin{array}{l}\text { participants in a diabetes } \\
\text { screening programme of } \\
\text { a department of diabetology, } \\
\text { having at least } 1 \text { risk factor for } \\
\text { diabetes (Bulgaria) }\end{array}$ & 2169 & 50.3 & $\geq 12$ & $\begin{array}{l}\text { WHO definition based on } \\
\text { the oral glucose tolerance } \\
\text { test of IFG, IGT or } \\
\text { diabetes* }\end{array}$ & 84.0 & 62.0 \\
\hline $\begin{array}{l}\text { Makrilakis } \\
\text { et al. [13] }\end{array}$ & $\begin{array}{l}\text { subjects } 35-75 \text { years who agreed } \\
\text { to participate in a screening } \\
\text { program for type } 2 \text { diabetes } \\
\text { after completing the FINDRISC } \\
\text { questionnaire (Greece) }\end{array}$ & 869 & 56.2 & $\begin{array}{l}\geq 10 \\
\geq 15\end{array}$ & $\begin{array}{l}\text { WHO definition based on } \\
\text { the oral glucose tolerance } \\
\text { test of IFG, IGT or } \\
\text { diabetes* }\end{array}$ & $\begin{array}{l}87.4 \\
67.7\end{array}$ & $\begin{array}{l}33.9 \\
67.2\end{array}$ \\
\hline \multirow[t]{2}{*}{$\begin{array}{l}\text { Costa } \\
\quad \text { et al. [14] }\end{array}$} & $\begin{array}{l}\text { subjects } 45-75 \text { years randomly } \\
\text { picked from primary healthcare } \\
\text { centers; all participants } \\
\text { with FINDRISC } \geq 15 \text { were } \\
\text { asked to undergo a blood test, } \\
\text { those with FINDRISC }<15 \text { were } \\
\text { offered a blood test if they wished } \\
\text { (Catalonia, Spain) }\end{array}$ & 3120 & 60.1 & $\geq 14$ & $\begin{array}{l}\text { WHO definition based on } \\
\text { the oral glucose tolerance } \\
\text { test of IFG, IGT or } \\
\text { diabetes* } \\
\text { ADA criteria based } \\
\text { on FPG of IFG or } \\
\text { diabetes** }\end{array}$ & 65.8 & 56.6 \\
\hline & & & & $\geq 14$ & haemoglobin $(\mathrm{Hb}) \mathrm{A} 1 \mathrm{c}^{* * *}$ & 54.4 & 51.3 \\
\hline
\end{tabular}


the studies depending on the studied population. Hence, the recruitment of the study populations easily creates a bias towards subjects with higher diabetes risk, which is reflected in the higher mean age.

The subjects that Tankova et al. have enrolled were referred by specialists as well as by general practitioners after an advertisement in local media, and had at least 1 risk factor for diabetes [12]. Makrilakis et al. have distributed the FINDRISC questionnaire among 7900 individuals, asking them afterwards to participate in a screening program for type 2 diabetes [13]. One can presume persons with a higher risk score were more motivated to participate. Costa et al. have solely asked participants with FINDRISC $\geq 15$ to undergo a blood test, while for those with FINDRISC $<15$ a blood the test was voluntary [14]. Other factors influencing sensitivity and specificity results were the different cut-off values for the FINDRISC questionnaire and different definitions, and criteria used for the diagnosis of diabetes and prediabetes [12-14].

In conclusion, a considerable number of workers had dysglycaemia or was at a risk of developing diabetes. The FINDRISC questionnaire was perceived a reliable, valuable and easy to use screening tool for dysglycaemia in occupational health surveillance. Nevertheless, further investigation on a large population of workers is needed in order to determine the best cut-off value of the FINDRISC questionnaire to be used in $\mathrm{OHC}$ for referral for diagnostic evaluation of dysglycaemia.

\section{REFERENCES}

1. Rey A, Thoenes M, Fimmers R, Meier C, Bramlage P. Diabetes prevalence and metabolic risk profile in an unselected population visiting pharmacies in Switzerland. Vasc Health Risk Manag. 2012;8:541-7, http://dx.doi.org/10.2147/VHRM. S35896.

2. Hauner H, Hanisch J, Bramlage P, Steinhagen-Thiessen E, Schunkert H, Jökel KH, et al. Prevalence of undiagnosed type-2-diabetes mellitus and impaired fasting glucose in
German primary care: Data from the German Metabolic and Cardiovascular Risk Project (GEMCAS). Exp Clin Endocrinol Diabetes. 2008;116(1):18-25, http://dx.doi.org/ 10.1055/s-2007-985359.

3. Viitasalo K, Lindström J, Hemiö K, Puttonen S, Koho A, Härmä $\mathrm{M}$, et al. Occupational health care identifies risk for type 2 diabetes and cardiovascular disease. Prim Care Diabetes. 2012;6(2):95-102, http://dx.doi.org/10.1016/j.pcd. 2012.01.003.

4. Dray-Spira R, Herquelot E, Bonenfant S, Guéguen A, Melchior M. Impact of diabetes mellitus onset on sickness absence from work - A 15-year follow-up of the GAZEL Occupational Cohort Study. Diabet Med. 2013;30(5):549-56, http://dx.doi.org/10.1111/dme.12076.

5. Alberti K, Zimmet P, Shaw J. International Diabetes Federation: A consensus on type 2 diabetes prevention. Diabet Med. 2007;24(5):451-63, http://dx.doi.org/10.1111/j.14645491.2007.02157.x.

6. Paulweber P, Valensi P, Lindström J, Lalic N, Greaves C, McKee $\mathrm{M}$, et al. A European evidence-based guideline for the prevention of type 2 diabetes. Horm Metab Res. 2010;42 Suppl 1:S3-36, http://dx.doi.org/10.1055/s-00291240928.

7. Lindström J, Tuomilehto J. The diabetes risk score: A practical tool to predict type 2 diabetes risk. Diabetes Care. 2003;26(3):725-31, http://dx.doi.org/10.2337/diacare. 26.3.725.

8. European Agency for Safety and Health at Work (OSHA). Facts 94: Workplace health promotion for employees [cited 2014 Jul 15]. Available from: https://osha.europa.eu/en/ publications/factsheets/94.

9. World Health Organization. Definition and diagnosis of diabetes mellitus and intermediate hyperglycemia. Report of a WHO/IDF consultation. Geneva: WHO; 2006.

10. DEHKO - Development programme for the prevention and care of diabetes in Finland 2000-2010. Progamme for the prevention of type 2 diabetes in Finland 2003-2010. Finnish Diabetes Association; 2003. 
11. Gyberg V, Hasson D, Tuomilehto J, Rydén L. Measuring risk online - Feasibility of using FINDRISC in an online workplace survey. Prim Care Diabetes. 2012;6(2):103-7, http:// dx.doi.org/10.1016/j.pcd.2011.12.003.

12. Tankova T, Chakarova N, Atanassova I, Dakovska L. Evaluation of the Finnish Diabetes Risk Score as a screening tool for impaired fasting glucose, impaired glucose tolerance and undetected diabetes. Diabetes Res Clin Pract. 2011;92(1): 46-52, http://dx.doi.org/10.1016/j.diabres.2010.12.020.

13. Makrilakis K, Liatis S, Grammatikou S, Perrea D, Stathi C, Tsiligros $\mathrm{P}$, et al. Validation of the Finnish diabetes risk score (FINDRISC) questionnaire for screening for undiagnosed type 2 diabetes, dysglycaemia and the metabolic syndrome in Greece. Diabetes Metab. 2011;37(2):144-51, http://dx.doi.org/10.1016/j.diabet.2010.09.006.

14. Costa B, Barrio F, Piñol J, Cabré J, Mundet X, Sagarra R, et al. Shifting from glucose diagnosis to the new HbA1c diagnosis reduces the capability of the Finnish Diabetes Risk Score (FINDRISC) to screen for glucose abnormalities within a real-life primary care healthcare preventive strategy. BMC Med. 2013;11:45, http://dx.doi.org/10.1186/17417015-11-45.

This work is available in Open Access model and licensed under a Creative Commons Attribution-NonCommercial 3.0 Poland License - http://creativecommons.org/ licenses/by-nc/3.0/pl/deed.en. 